\title{
Family Reunification Following Foster Care ${ }^{1}$
}

\author{
Rosalyn Monroe and Victor W. Harris ${ }^{2}$
}

All families need support. It is essential to promote child safety, development, and well-being. All parents can also benefit from helpful information, guidance, and resources as they meet the challenges of parenthood and family life. This is especially true after a family goes through a crisis that separates family members because of abuse or neglect and results in an intervention from child protective services to ensure safety.

Families preparing to reunify after a separation because of abuse or neglect face unique challenges in their attempts to come back together. Parents must ensure they provide and maintain a safe home environment for their children and resolve personal challenges that may impair their ability to parent effectively (Child Welfare Information Gateway, 2012). Court-mandated parenting courses often provide the skills, resources, and education necessary to meet and manage the demands of parenting for families in crisis (Hatton \& Brooks, 2008).

Because family reunification is the most common goal for children in foster care or other "out-of-home" placement, practitioners must place careful attention on the guiding principles and practices discussed in mandated parenting courses (Child Welfare Information Gateway, 2012). These guiding principles and practices include educating parents on the basic and essential needs for healthy development of their children, understanding their role as parents, and identifying helpful internal and external resources that promote family reunification and prevent their children's

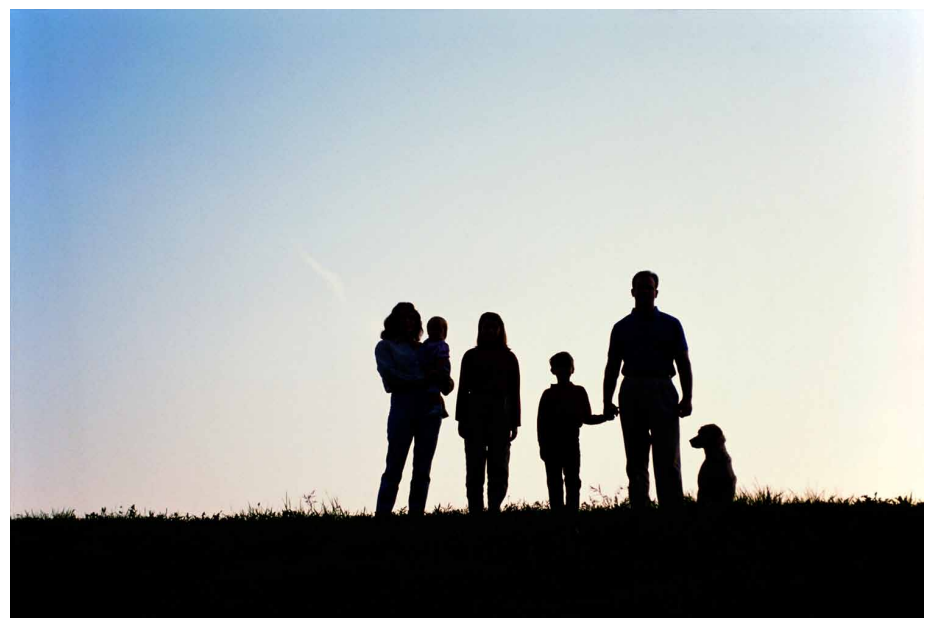

Figure 1. Families reuniting after an intervention that requires foster care for the children face unique challenges. Parents in these situations may need to learn about their parental roles, the basic needs for the healthy development of their children, and resources that will help the family in their reunification.

Credits: Jupiterimages

re-entry into the foster care or child welfare system (Hatton \& Brooks, 2008; Cheng, 2010).

Researchers and practitioners in child welfare have provided helpful information to develop workable plans to aid families in reunifying and rebuilding. The following publication is a brief summary of the overarching themes provided by the literature (Barth, Weigensberg, Fisher, Fetrow, \& Green 2008; Brook \& McDonald, 2009; Cheng, 2010; Child Welfare Information Gateway, 2012; Hatton \& Brooks, 2008; Leathers, Falconnier, \& Spielfogel, 2010; Madden et al., 2012).

1. This document is FCS2328, one of a series of the Department of Family, Youth and Community Sciences, Florida Cooperative Extension Service, Institute of Food and Agricultural Sciences, University of Florida. Original publication date April 2013. Visit the EDIS website at http://edis.ifas.ufledu.

2. Rosalyn Monroe, graduate student, Department of Family, Youth and Community Sciences; and Victor W. Harris, assistant professor and family life education Extension specialist, Department of Family, Youth and Community Sciences; Florida Cooperative Extension Service, Institute of Food and Agricultural Sciences, University of Florida, Gainesville, FL 32611. 


\section{Helpful Information}

\section{What Do Children Need?}

One of the foremost reasons family reunification fails after children in protective care return to their parents is neglect (Barth et al., 2008; Brook \& McDonald, 2009). Although parents may have worked diligently to meet the requirements necessary to have their child or children returned to their care, in some cases parents are unsuccessful in their attempts once the children return. When this occurs, the children are often removed from their parents' care and placed back into foster care or a protective care setting. Because there is a greater risk for some families to re-enter the protective care systems, parents of children in protective care need to know and understand that children have specific needs that must be met if they are to achieve healthy growth and development (Steinberg, 2004; Welch, 2010). Although parents may have already received this information as required for reunification, parents seeking reunification with their children may find it helpful to review and readdress the needs of children. For example, children need to:

\section{FEEL SAFE AND SECURE}

Consistency is key to helping children feel safe and secure. Children, especially infants and toddlers, need to feel that their caregivers provide a place of safety and comfort. This also includes a secure understanding that their parents and caregivers will consistently provide food, proper clothing, and adequate shelter (Steinberg, 2004; Welch, 2010).

\section{FEEL LOVED AND VALUED}

Children need to feel loved, valued, and respected at all stages of development and growth. The impact of emotional abuse is as damaging on children as physical abuse. There is no one correct method of showing love and affection, but parents in the process of reunification, or those who have been reunited with their children in protective care, must understand and meet both the physical and emotional needs of their children (Steinberg, 2004; Welch, 2010).

\section{EXPERIENCE RULES, LIMITS, EXPECTATIONS, AND DISCIPLINE}

Every child needs rules, limits, expectations, and discipline. Reunified parents need to understand why children benefit from rules, limits, expectations, and discipline, and they need to know what is acceptable with regard to setting rules, limits, expectations, and discipline. Abusive parents tend to be overly harsh and demanding in each of these areas (Steinberg, 2004; Welch, 2010).

\section{Things You Can Do}

\section{Four Steps to Promote and Maintain Family Reunification}

It is a traumatic experience when a child is removed from his or her home, no matter the condition or status of the home (Barth et al., 2008). This is the reason that great effort and attention are directed toward reunifying families involved in the child welfare system. Because reunification is usually the ultimate goal, practical steps must be followed to support families both before and after reunification. This support includes every effort to prevent a future separation because of parental abuse or neglect. The following steps can be taken to address recurring issues that may impede or break down the reunification process (Hatton \& Brooks, 2008; Brook \& McDonald, 2009; Cheng, 2010; Child Welfare Information Gateway, 2012; and Madden et al., 2012).

\section{Beginning Family Reunification Prior to Re-entry} into the Home - Parents and children must re-establish the parent-child relationship that may be disrupted because of the child's removal from the home (Child Welfare Information Gateway, 2012). This can be done by following court-ordered visitation plans that allow the family to slowly reconnect and establish healthy bonds with one another.

\section{Establishing and Making Use of Supportive Services}

- Many factors impact the parents' ability to adequately parent. Supportive services can help parents ensure that the basic needs of their children are being met. Some helpful supportive services that promote family reunification and stability are listed below.

- Medical - Regardless of cost, a child's health cannot be neglected. Parents must ensure that their children receive adequate medical care when needed. Local county and city health departments provide a variety of free and low-cost services for the entire family. These services may include primary care, STD testing/counseling, immunizations, and referral medical services. Medicaid, Medicare, and other health assistance plans may be available for those that qualify.

- Housing/Food Assistance - As with medical care, parents and caregivers are responsible for ensuring that their children have sufficient access to safe housing and food. Subsidized housing and nutrition assistance programs provide access to low-cost housing options and supplemental food programs to families and individuals in need. These services are provided through income-restricted 
housing options, voucher programs, or monthly stipends. Federally funded programs, such as SNAP (Supplemental Food Assistance Program) and WIC (Women, Infant, and Children), provide access and education for healthy nutrition and food choices.

- Financial Assistance - Programs such as Temporary Assistance for Needy Families (TANF) and the Low Income Home Energy Assistance Program (LiHEAP, a home utility assistance program) can ease the financial burden that may accompany meeting the needs of a growing family. Parents must not only make provision for safe housing, but they must also ensure that living spaces have adequate amenities such as electricity, running water, and furniture. Financial aid programs such as TANF and LiHEAP can assist parents, especially those in the process of rebuilding and reunifying, to ensure that they meet and maintain basic provisions for their families.

- Child Care or Children Services - Subsidized child care services provide parents the opportunity to ensure that their children will receive adequate child care when needed at little to no cost. This supports efforts to ensure that children are not left alone to care for themselves when parents are away. Aside from child care, these services should also include schooling, extracurricular, and enrichment programs that benefit the child.

- Substance Abuse/Mental Health Services - Alcoholics Anonymous and Narcotics Anonymous (AA/NA) programs and mental health counseling offer continued support for families rebuilding after reunification. These programs support sobriety and promote healing within the family when a crisis or separation caused by abuse or neglect has been experienced.

\section{Identify External and Internal Support Systems -} External and internal support systems provide reunified families with a safe and stable outlet during difficult or stressful periods (Cheng, 2010). Internal support systems can include close family members or friends familiar with the family's history who are willing to serve as an outlet and pillar of support. External support systems may include friends or neighbors, religious leaders, or support groups connected to the family in a manner that allows for emotional support during difficult or stressful times. Parents and children alike should be encouraged to develop similar but separate support systems consisting of stable and responsible individuals or groups.

4. Time Management - Time management can strengthen the organization of daily household activities. For some parents, the stress of managing a household and caring for children can be burdensome. This may lead to parents becoming overwhelmed with stress, which could lead to negative and harmful reactions toward their children. The development of a practical and realistic time management system and schedule can assist families in ensuring daily activities are achieved with little, if any, stress. Time management systems should also include personal time for both parents and children so that they have opportunities to reduce stress and promote positive family environments.

\section{Things You Can Use}

\section{External and Internal Support Systems}

The idea of creating a support base for both parents and children as they rebuild family bonds is much easier to achieve than actually identifying a person or group willing to provide support during difficult periods. Table 1 provides an opportunity for both parents and children to clearly identify family members, friends, neighbors, or community groups willing to provide support or a safe outlet when needed. Filling out Table 1 can help families discuss needs, concerns, and guidelines for using respective support systems.

The Family Reunification Tracking Checklist found in Table 1 will provide guidance for families as they identify and construct their support system contact list. Table 1 can be modified and used as a reference for a number of supportive services discussed in this publication. Because families may face many challenges to their reunification process after post-protective care, both parents and children can benefit by creating support systems for other areas in their lives. The Family Support System Contact List found in Table 2 can be a great resource for this effort.

\section{Conclusion}

The general consensus within the child welfare system is that children tend to thrive when placed in their own family settings. This often means that the preferred goal for children in foster or protective care is to return to a safe family and home environment, if possible. Parents play a key role in this reunification process because they are the primary providers of their children's basic needs. Although barriers and challenges exist for families rebuilding after foster care, these families can take certain measures to support the reunification process. Parents can be encouraged to make use of the steps discussed in this publication to support personal reunification efforts with their children. Support systems provide a helpful and healthy resource for 
both parents and children during stressful times so that families can persevere and remain intact.

\section{References}

Barth, R. P., Weigensberg, E. C., Fisher, P. A., Fetrow, B., \& Green, R. L. (2008). Reentry of elementary aged children following reunification from foster care. Children and Youth Services Review, 30(4), 353-364.

Brook, J., \& McDonald, T. (2009). The impact of parental substance abuse on the stability of family reunifications from foster care. Children and Youth Services Review, 31(2), 193-198.

Cheng, T. C. (2010). Factors associated with reunification: A longitudinal analysis of long-term foster care. Children and Youth Services Review, 32(10), 1311-1316.

Child Welfare Information Gateway. (2012). Supporting reunification and preventing reentry into out-of-home care. Washington, D.C.: U.S. Department of Health and Human Services, Children's Bureau.

Hatton, H., \& Brooks, S. (2008). Preventing re-entry into the child welfare system: A literature review of promising practices. Northern California Training Academy: The Center for Human Services. Retrieved from http://www. childsworld.ca.gov/res/pdf/PreventingRe-entry.pdf

Leathers, S. J., Falconnier, L., \& Spielfogel, J. E. (2010). Predicting family reunification, adoption, and subsidized guardianship among adolescents in foster care. The American Journal of Orthopsychiatry, 80(3), 422-431.

Madden, E. E., Maher, E. J., McRoy, R. G., Ward, K. J., Peveto, L., \& Stanley, A. (2012). Family reunification of youth in foster care with complex mental health needs: Barriers and recommendations. Child and Adolescent Social Work Journal, 29(3), 221-240.

Steinberg, L. (2004). The 10 basic principles of good parenting. New York: Simon \& Schuster.

Welch, K. J. (2010). Family life now (2nd ed.). Boston: Allyn \& Bacon. 
Table 1. Family Reunification Tracking Checklist

\begin{tabular}{|c|c|c|c|}
\hline Task & Building your family support system & $\sqrt{ }$ & Notes \\
\hline 1 & $\begin{array}{l}\text { Identify needs for support systems. (Compile your } \\
\text { needs in the Notes column.) }\end{array}$ & & \\
\hline 2 & $\begin{array}{l}\text { Identify at least five separate individuals or groups who } \\
\text { can serve as personal support systems (i.e., internal and } \\
\text { external support systems) for both you and your child } \\
\text { to help you meet the needs identified. (Compile a list in } \\
\text { the Notes column.) }\end{array}$ & & $\begin{array}{l}1 . \\
2 . \\
3 . \\
4 . \\
5 . \\
6 . \\
7 . \\
8 . \\
9 . \\
10 .\end{array}$ \\
\hline 3 & $\begin{array}{l}\text { Identify any additional individuals or groups who may } \\
\text { be willing to serve as a system of support. } \\
\text { (Identify these individuals in the Notes column.) }\end{array}$ & & $\begin{array}{l}\text { Internal Support: } \\
\text { External Support: }\end{array}$ \\
\hline 4 & $\begin{array}{l}\text { Discuss your needs with the individuals and groups on } \\
\text { your list and your child's list. }\end{array}$ & & \\
\hline 5 & $\begin{array}{l}\text { Complete the Family Support System Contact List (Table } \\
\text { 2). }\end{array}$ & & \\
\hline
\end{tabular}

Table 2. Family Support System Contact List

\begin{tabular}{|l|l|l|}
\hline & External & Internal \\
\hline Parent & $\begin{array}{l}\text { Name: } \\
\text { Contact Information: }\end{array}$ & $\begin{array}{l}\text { Name: } \\
\text { Contact Information: }\end{array}$ \\
\hline & Name: & $\begin{array}{l}\text { Name: } \\
\text { Contact Information: }\end{array}$ \\
\hline & Name: & Contact Information: \\
\hline & Contact Information: & Contact Information: \\
\hline Child/Children & Name: & Name: \\
$\mathbf{1}$ per child) & Contact Information: & Contact Information: \\
\hline & Name: & Name: \\
& Contact Information: & Contact Information: \\
\hline & Name: & Name: \\
& Contact Information: & Contact Information: \\
\hline & Name: & Name: \\
& Contact Information: & Contact Information: \\
\hline & Name: & Name: \\
& Contact Information: & Contact Information: \\
\hline
\end{tabular}

